\title{
Corneal sensitivity in five horse breeds
}

\section{Eunice Santos de Andrade ${ }^{1}$ João Victor Romano Vieira ${ }^{1}$ Deusdete Conceição Gomes Júnior ${ }^{2}$ Ana Claúdia Santos Raposo ${ }^{1}$ Paula Diniz Galera ${ }^{3}$ Arianne Pontes Oriá ${ }^{1}$}

${ }^{1}$ Escola de Medicina Veterinária e Zootecnia, Universidade Federal da Bahia (UFBA), Av. Ademar de Barros, s/n, Ondina, 40170-110, Salvador, BA, Brasil.

${ }^{2}$ Faculdade de Ciências Agrárias e da Saúde, União Metropolitana de Educação e Cultura, Lauro de Freitas, BA, Brasil.

${ }^{3}$ Departamento de Medicina Veterinária, Escola de Medicina Veterinária, Universidade de Brasília (UNB), Brasília, DF, Brasil.

\begin{abstract}
This study aimed to determine and compare corneal sensitivity values in different regions of the cornea in five horse breeds. One hundred and forty five healthy horses, adults of both sexes, of the following breeds -Arabian horse (AH; $n=20)$, Mangalarga Marchador (MM; $n=50)$, Pure Blood Lusitano (PBL; $n=35)$, Quarter Horse $(Q H ; n=20)$, Brazilian Sport Horse (BSH; $n=20)$-were investigated. Corneal touch threshold (CTT) was measured with a Cochet-Bonnet esthesiometer in five different corneal regions. Measurements of the median central CTT were: $4.50 \pm 0.50 \mathrm{~cm}(A H), 3.50 \pm 0.56 \mathrm{~cm}(M M), 3.00 \pm 0.25 \mathrm{~cm}(P B L), 2.50 \pm 0.44 \mathrm{~cm}(Q H)$ and $2.50 \pm 0.00 \mathrm{~cm}(B S H)$. The central region was the most sensitive and the dorsal region the least sensitive corneal region for all breeds. CTT values differed for corneal regions and horse breeds. The CTT values were different among the corneal regions and the horse breeds. Arabian horses presented higher sensitivity values being the most sensitive in all of the corneal regions.
\end{abstract}

Key words: Arabian horse, Equus caballus, Cochet-Bonnet, corneal touch threshold.

Sensibilidade corneana em cinco raças de equinos

RESUMO: Objetivou-se com o presente estudo, determinar e comparar valores de sensibilidade corneana em diferentes regiões da córnea em cinco raças de equinos. Foram investigados 145 equinos hígidos, adultos de ambos os sexos, das raças: Puro Sangue Árabe (PSA; $n=20)$, Mangalarga Marchador (MM; n=50), Puro Sangue Lusitano (PBL; n=35), Quarto de Milha (QH; $n=20)$ e Brasileiro de Hipismo (BSH; $n=20)$. O limiar táctil da córnea (LTC) foi mensurado com o auxílio do estesiômetro de Cochet-Bonnet, em cinco diferentes regiões da córnea

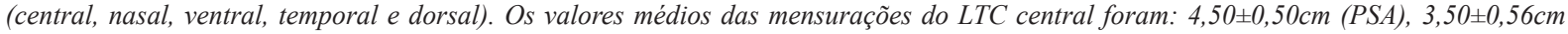

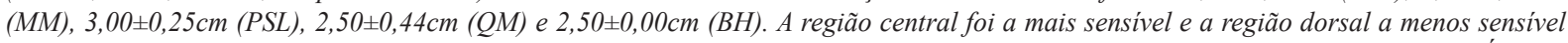
para todas as raças. Os valores de LTC diferiram para as regiões da córnea e entre as raças dos cavalos, sendo a raça Puro Sangue Árabe o que apresentou valores maiores de sensibilidade, desta forma sendo o mais sensivel em todas as regiões corneanas.

Palavras-chave: Puro Sangue Árabe, Eqqus caballus, Cochet-Bonnet, limiar táctil corneano.

\section{INTRODUCTION}

Equine corneal diseases are recurring because the activities in which this species is inserted, such as horseback riding, racing, riding and working in the field (BARRET et al., 1991; REICHMANN et al., 2008). Thus, they are subject to frequent injury to the cornea and conjunctiva concomitant with pain and discomfort and depending on the degree of vision impairment, the animal may become unusable for work (LAVACH, 1990; BROOKS \& MATTHEWS, 2007).

Corneal sensitivity has alert function for possible injuries or diseases (BROOKS et al., 2000). In horses, the sensitivity values are higher compared to other animals such as dogs and cattle (KAPS et al., 2003; WIESER et al., 2013). It can be affected by several factors, including the skull anatomy and orbit that change the positioning and insertion of the eyeball in each breed, ambient temperature and humidity and age of the individual (LACERDA et al., 2014; MONÇÃO-SILVA et al., 2016). Factors that may influence the corneal touch threshold (CTT) values have already been studied in horses (BROOKS et al., 2000; KAPS et al., 2003; WIESER et al., 2013), birds (LACERDA et al., 2014), dogs (KOBASHIGAWA et al., 2015) and cats (BLOCKER \& VAN DER WOERT, 2001). However, studies that addressed the mechanism and values of corneal sensitivity in horses are scarce, and when carried out, data were reported 
without breed subdivision (BROOKS et al., 2001; KAPS et al., 2003; WIESER et al., 2013).

The degree of corneal surface stimulation necessary to cause a blink reflex has been measured in humans and rabbits with the platinum filament of the Larson-Millodot aesthesiometer, and dogs and cats with the nylon filament of the Cochet-Bonnet aesthesiometer (DE FELIPE et al., 1999; BLOCKER \& VAN DER WOERT, 2001; GOLEBIOWSKY et al., 2011). The Cochet-Bonnet esthesiometer is used to determine the corneal touch threshold (CTT), at which a blink reflex, retraction of the eyeball or incursion of the third eyelid is induced in response to a stimulus (MULLER et al., 2003; KAPS et al., 2003; WIESER et al., 2013).

The aim of the present study was to establish reference values and compare the results for sensitivity of the different corneal regions in the adults Arabian horse (AH), Mangalarga Marchador (MM), Pure Blood Lusitano (PBL), Quarter Horse $(\mathrm{QH})$ and Brazilian Sport Horse (BSH) breeds.

\section{MATERIALS AND METHODS}

One hundred and forty-five healthy adult horses, of both genders, from private horse farms, were used in this investigation: Pure Arabian Blood $(n=20)$, Mangalarga Marchador $(n=50)$, Pure Blood Lusitanian $(n=35)$, Quarter Horses $(n=20)$ and the Brazilian Equestrian $(n=20)$. The examination was performed in outdoor enclosures and measurements were then registered with the breeds' respective associations along with certification for the breed to which each of them belonged.

Before the study, each animal was subjected to a complete physical examination. Animals with signs of systemic disease (clinical or laboratory), pregnancy, analgesic or anti-inflammatory use, or periocular or ophthalmic disease were excluded. The tests were performed between 08 and $11 \mathrm{~h}$, with temperatures ranging from 27 to $30.5^{\circ} \mathrm{C}$ and humidity from 55 to $65 \%$. Only cooperative, non-sedated horses were used. The aqueous portion of the tear film was measured in the left eye using sterile Schirmer tear test strips (Ophthalmos ${ }^{\circledR}$, São Paulo, Brazil) and horses with less than $15 \mathrm{~mm} \mathrm{~min}^{-1}$ of tear production were excluded.

Corneal touch threshold (CTT) was measured in the right eye of each horse in the nasal, ventral, dorsal and temporal regions, approximately $2 \mathrm{~mm}$ from the limbus, and in the center of the cornea, using a Cochet-Bonnet esthesiometer (Luneau Ophthalmologie, Chartres Cedex, France) (Figure 1).
The procedure was performed by gently touching the cornea with a nylon filament, $0.12 \mathrm{~mm}$ in diameter. The maximal length of the filament $(6 \mathrm{~cm})$ was used in the initial test, in which the cornea was touched three times in an attempt to elicit a blink reflex. If no reflex was observed, the filament length was reduced by $0.5 \mathrm{~cm}$, and the test was repeated until reflexes were elicited for all three contacts, or until the shortest length $(0.5 \mathrm{~cm})$ was reached. The final filament length was recorded in centimeters, with higher values corresponding to greater corneal sensitivity. After investigation the periocular region and anterior segment of both eyes were evaluated and stained with fluorescein dye $\left(\right.$ Ophthalmos $\left.^{\circledR}\right)$ to exclude animals with corneal lesions.

Statistical analysis was conducted with SPSS version 2.2 (IBM). Shapiro-Wilk test was used to assess the normality of the variables. Kruskal-Wallis test was used for comparisons of variables among the different breeds. Friedman test was used for comparison between corneal regions in the same breed. To evaluate the effect of gender on the central CTT, the Mann-Whitney test was used and the association between age and central CTT was assessed using Pearson's correlation coefficient. For all analyses, $\mathrm{P}<0.05$ was considered significant.

\section{RESULTS}

The results obtained for Schirmer tear test I (STT-I) were normally distributed according to Shapiro-Wilk test, and there were no significant differences between gender and ages. The mean $( \pm$ SD) STT-I values were all above $15 \mathrm{~mm}$ in all groups.

When measuring the CTT, a greater sensitivity reflex, manifested as retraction of the eye and eyelids, was reported in the $\mathrm{AH}$ relative to other breeds. In the other studied breeds, normal reflex of eyelid incursion was observed in $\mathrm{AH}$, without the same intensity.

The median ( \pm S-IQR) CTT values of the corneal regions are presented in table 1 . The CTT values for the central region were significantly different among breeds (Figure 1), with the AH being the most sensitive and the $\mathrm{QH}$ and $\mathrm{BSH}$ the least sensitive for this region. The MM and PBL horses presented similar values.

The central region was the most sensitive, followed by the nasal, temporal, ventral and dorsal regions, the latter being the least sensitive $(\mathrm{P}<0.05)$ (Figure 2). Regional significant variation in corneal sensitivity was identified $(\mathrm{P}<0.05)$. 


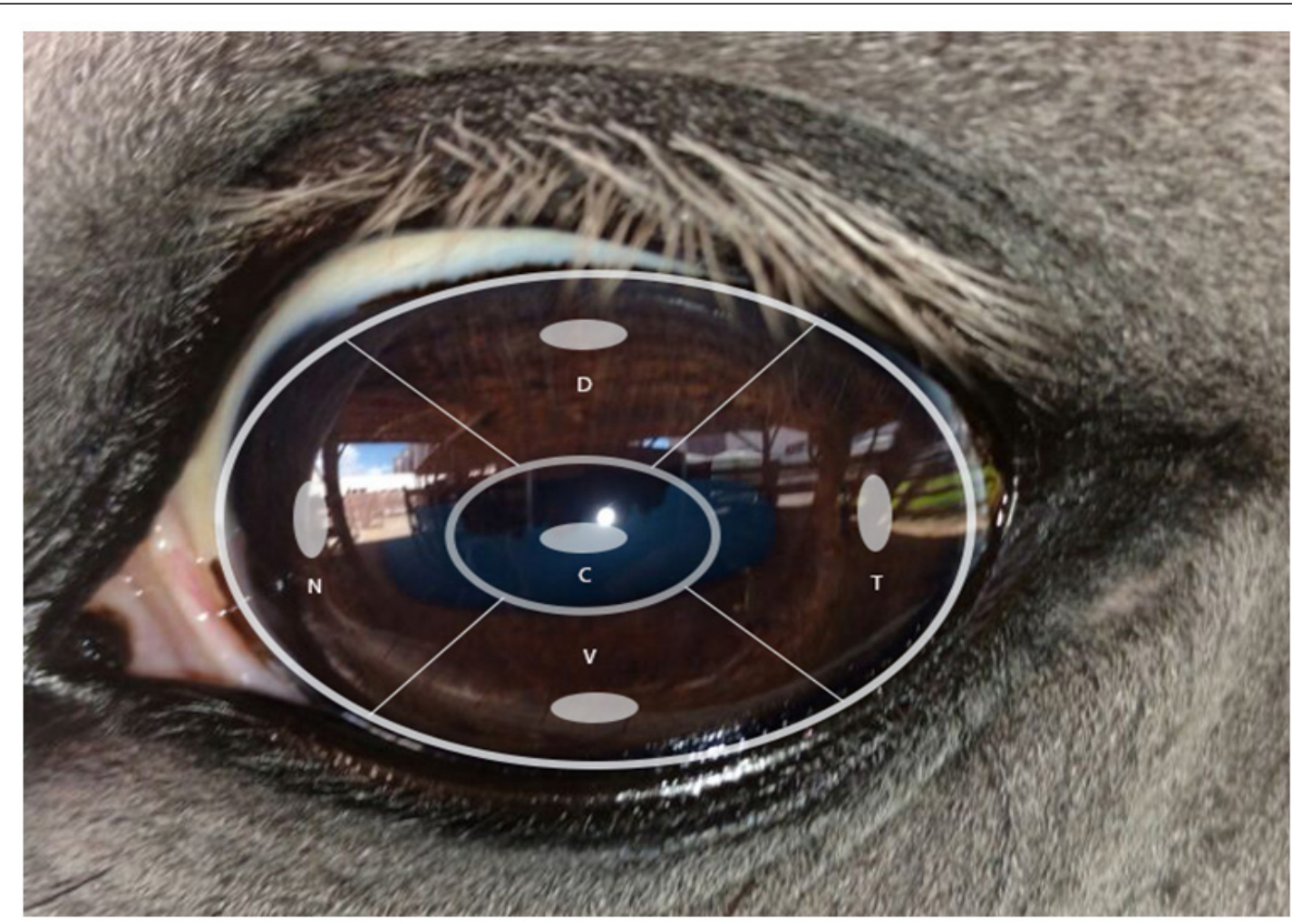

Figure 1 - The five regions of the cornea evaluated. $\mathrm{D}=$ Dorsal, $\mathrm{T}=$ Temporal, $\mathrm{V}=$ Ventral, $\mathrm{N}=\mathrm{Nasal}$ and $\mathrm{C}=\mathrm{Central}$.

\section{DISCUSSION}

Esthesiometry has been studied in different species, including humans (GOLEBIOWSY et al., 2011), cats (CHANG-LING, 1989; BLOCKER \& VAN DER WOERT, 2001; WIESER et al., 2013), rabbits (WIESER et al., 2013), dogs (BARRETT et al., 1991;
WIESER et al., 2013; KOBASHIGAWA et al., 2015), chinchillas (LIMA et al., 2010; MULLER et al., 2010), alpacas (WELIHOZKIY et al., 2011; RANKIN et al., 2012), goat, guinea pigs, cows and sheep (WIESER et al., 2013), birds (LACERDA et al., 2014), turtles (SOMMA et al., 2015) and horses (BROOKS et al., 2001; KAPS et al., 2003; WIESER et al., 2013).

Table 1 - Median values \pm semi-interquartile range of corneal touch threshold for central, nasal, temporal, ventral and dorsal corneal regions of 145 healthy adult horses.

\begin{tabular}{lccccc}
\hline Breeds & Central & Nasal & Temporal & Ventral & Dorsal \\
\hline PSA & $4.50 \pm 0.50^{\mathrm{a}}$ & $4.00 \pm 0.25^{\mathrm{b}}$ & $3.25 \pm 0.50^{\mathrm{bc}}$ & $3.10 \pm 0.50^{\mathrm{bc}}$ & $3.00 \pm 0.06^{\mathrm{c}}$ \\
MM & $3.50 \pm 0.56^{\mathrm{a}}$ & $3.50 \pm 0.56^{\mathrm{a}}$ & $3.00 \pm 0.50^{\mathrm{b}}$ & $3.00 \pm 0.50^{\mathrm{b}}$ & $2.00 \pm 0.25^{\mathrm{c}}$ \\
PSL & $3.00 \pm 0.25^{\mathrm{a}}$ & $3.00 \pm 0.25^{\mathrm{a}}$ & $2.50 \pm 0.50^{\mathrm{b}}$ & $2.50 \pm 0.50^{\mathrm{b}}$ & $1.00 \pm 0.50^{\mathrm{c}}$ \\
QM & $2.50 \pm 0.44^{\mathrm{a}}$ & $2.50 \pm 0.50^{\mathrm{a}}$ & $2.00 \pm 0.44^{\mathrm{b}}$ & $2.00 \pm 0.44^{\mathrm{b}}$ & $1.00 \pm 0.25^{\mathrm{c}}$ \\
BH & $2.50 \pm 0.00^{\mathrm{a}}$ & $2.50 \pm 0.00^{\mathrm{a}}$ & $2.00 \pm 0.00^{\mathrm{b}}$ & $2.00 \pm 0.00^{\mathrm{b}}$ & $1.00 \pm 0.25^{\mathrm{c}}$ \\
\hline
\end{tabular}

AH - Arabian horse, MM - Mangalarga Marchador, PBL - Pure Blood Lusitano, QH - Quarter Horse, BSH - Brazilian Sport Horse. Different superscript letters indicate significant differences between corneal regions. 


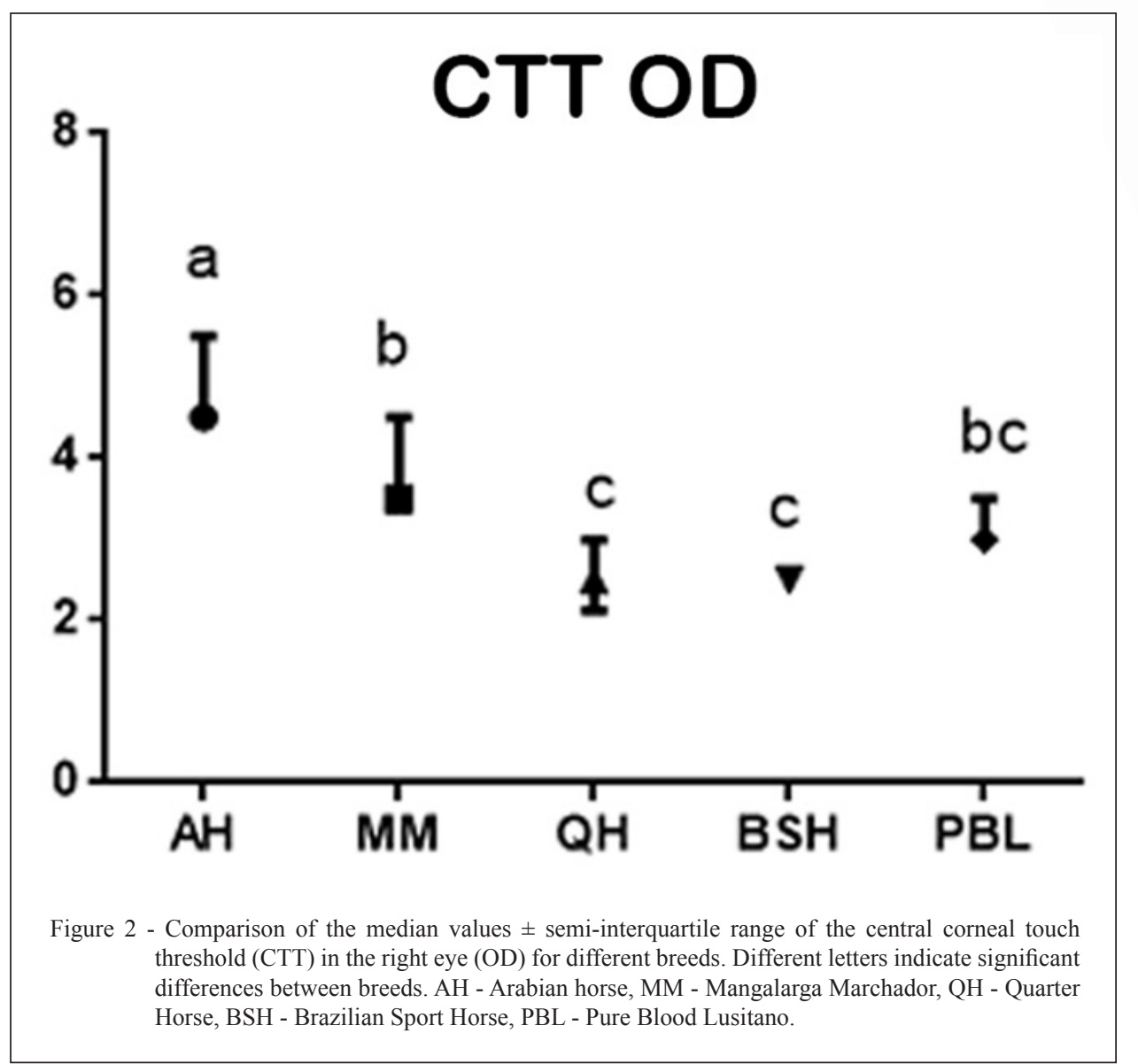

Previous investigations have shown no significant differences between an individual's two eyes with respect to CTT evaluations (GOLEBIOWSKY et al., 2011; WIESER et al., 2013). Moreover, two measurement results per animal can hinder the degrees of freedom in the statistical model, leading to a reduction in statistical power, and the need for a higher caseload (GOLEBIOWSKY et al., 2011). Therefore, since no additional information is gained by measuring both eyes of every individual (GOLEBIOWSKY et al., 2011; WIESER et al., 2013) we measured only one of their eyes.

The median CTT value for normal adult horses of a heterogeneous breed group is $5.5 \mathrm{~cm}$ (BROOKS et al., 2001), which differed from the median values reported in this study for $\mathrm{AH}, \mathrm{MM}$, $\mathrm{PBL}, \mathrm{QH}$ and $\mathrm{BSH}$ breeds. This variation might be associated to different densities of corneal innervations or to anatomy, use and skills of each breed, but these possibilities require further investigation (BROOKS et al., 2001; WIESER et al., 2013). CTT values reported in the present study were different than reported by BROOKS et al., 2001; KAPS et al., 2003; WIESER et al., 2013. In these studies, there was no results specific for breeds and the studied groups have consisted of few animals, with heterogeneous age range, including neonates and foals.

BROOKS et al. (2001) observed higher CTT values in neonates $(5.33 \pm 0.60 \mathrm{~cm})$ and adult $(5.54 \pm 0.57 \mathrm{~cm})$ horses of distinct breeds. KAPS et al. (2003) reported decreased values in 1 - 4 years foals $(23.64 \pm 4.41 \mathrm{~mm})$ and $5-10$ years $(21.25 \pm 5.97 \mathrm{~mm})$ and over 10 years $(19.17 \pm 7.20 \mathrm{~mm})$ adult animals. In addition, WIESER et al. (2013) reported decreased values $\left(1.23 \pm 1.07 \mathrm{~g} \mathrm{~mm}^{-2}\right)$ in a smaller and heterogeneous group. In the present study there was no significant difference when correlating the results of CTT with age and gender of the animals and within the groups (Table 2). We can then suggest, based in the proximity of the animals ages, that there is no influence of age and gender of animals in the CTT values found.

The nerve fiber density is greater in the central cornea of dogs, cats, rabbits and humans and 
Table 2 - Age and gender of 145 healthy adult horses.

\begin{tabular}{lcc}
\hline Breed - N & Age (years) & Gender \\
\hline AH - 20 & $6-8$ & 7 male -13 female \\
MM - 50 & $6-14$ & 16 male - 34 female \\
PBL - 35 & $7-14$ & 17 male - 18 female \\
QH - 20 & $7-11$ & 8 male - 12 female \\
BSH - 20 & $6-14$ & 12 male - 8 female \\
\hline
\end{tabular}

AH - Arabian horse, MM - Mangalarga Marchador, PBL - Pure Blood Lusitano, QH - Quarter Horse, BSH - Brazilian Sport Horse.

consequently, it is more sensitive than peripheral regions (CHANG-LING, 1989; BROOKS et al., 2001; GOLEBIOWSKY et al., 2011). This variation in ocular sensitivity might be related to genetics, management or anatomy of each breed. Other studies have shown differences in CTT values for the horse's different corneal regions, following the order (highest to lowest): central, nasal, temporal, ventral and dorsal (BROOKS et al., 2001; KAPS et al., 2003). In the breeds $\mathrm{MM}, \mathrm{QH}, \mathrm{PBL}$ and $\mathrm{BSH}$, there were similarities between central and nasal regions, as well as between ventral and temporal regions $(\mathrm{P}>0.05)$. This was not observed in the AH, which presented a statistically significant difference between the central region CTT and the other regions of the cornea $(\mathrm{P}<0.001)$

A statistically significant difference was observed between the dorsal corneal region and all other regions of the cornea within all breeds, similar to findings by BROOKS et al. (2001) and KAPS et al. (2003). The decreased sensitivity of this region might be due to reduced nerve supply, as well as to permanent contact of the superior eyelid, which might result in that region's adaptation to pressure during eyelid incursions (MILLODOT, 1984; KAPS et al., 2003).

The AH presented significant statistical differences from the other breeds in all regions, which could be justified by this breed's unique cranial shape and prominent eyes (SADEK et al., 2006). However, it should be noted that BLOCKER \& VAN DER WOERDT (2001) reported lower sensitivity of the central cornea in brachycephalic cats, which also have prominent eyes.

In cats, the combination of prominent eyes and decreased corneal sensitivity may make these animals more susceptible to chronic keratitis, corneal ulceration and corneal sequestrum (BLOCKER \& VAN DER WOERT, 2001). The QH presented the lowest central corneal sensitivity and this might explain the high incidence of ulcerative keratitis reported in this breed (DE LINDE HENRIKSEN et al., 2014).

Thus, considering the anatomical differences among breeds, the results of evaluations for CTT, among other parameters, should be compared whenever possible within the same breed, and the evaluations should be conducted under similar environmental conditions.

In the present study, significant differences of corneal sensitivity were observed for the different studied breeds. Arabian horses presented the highest sensitivity values among the other groups of studied breeds in all of the corneal regions, being the most sensitive.

\section{ACKNOWLEDGMENTS}

The authors would like to thank Fundação de Amparo à Pesquisa do Estado da Bahia (FAPESB) and Coordenação de Aperfeiçoamento de Pessoal de Nível Superior (CAPES).

\section{BIOTHICS AND BIOSSECURITY COMMITTE APRROVAL}

The study was approved by the Ethical Committee for Animal Use of the School of Veterinary Medicine and Zootechnology, Universidade Federal da Bahia (33/2015), and was conducted in accordance with the ARVO Statement for the Use of Animals in Ophthalmic and Vision Research.

\section{REFERENCES}

BARRETT, P.M. et al. Absolute corneal sensitivity and corneal trigeminal nerve anatomy in normal dogs. Progress in Veterinary and Comparative Ophthalmology, v.1, p.245-254, 1991. Available from: <http://www.scielo.br/scielo.php?script=sci nlinks\&ref $=000074 \&$ pid $=$ S0102-0935201200030000800003\&lng $=\mathrm{pt}>$. Accessed: Feb. 12, 2016.

BLOCKER, T.; VAN DER WOERDT, A. A comparison of corneal sensitivity between brachycephalic and domestic shorthaired cats. Veterinary Ophthalmology, v.4, p.127-130, 2001. Available from: <http://onlinelibrary.wiley.com/doi/10.1046/ 
j.1463-5224.2001.00189.x/>. Accessed: Jan. 11, 2016. doi: 10.1046/j.1463-5224.2001.00189.x.

BROOKS, D.E. et al. Cochet Bonnet aesthesiometerdetermined corneal sensitivity in neonatal foals and adult horses. Veterinary Ophthalmology, v.3, p.133-137, 2000 Avaliable from: <http://onlinelibrary.wiley.com/doi/10.1046/ j.1463-5224.2000.3230133.x/>. Accessed: Jan. 12, 2016 . doi: 10.1046/j.1463-5224.2000.3230133.x.

CHANG-LING T. Sensitivity and neural organization of the cat cornea. Investigative Ophthalmology and Visual Science, v.30, p.1075-1082, 1989. Available from: <http://iovs.arvojournals.org/ article.aspx? articleid=2178300>. Accessed: Jan. 12, 2016.

DE FELLIPE, C. et al. Quantification and immunocytochemical characteristics of trigeminal ganglion neurons projecting to the cornea: effect of corneal wounding. European Journal of Pain, v.3, p.32-39, 1999. Available from: <http://onlinelibrary.wiley. com/doi/10.1016/S1090801(99)90186/>. Accessed: Feb. 10, 2016. doi: 10.1053/eujp.1998.0100

DE LINDE HENRIKSEN, M. et al. Equine deep stromal abscesses (51 cases - 2004-2009)-Part 1: the clinical aspects with attention to the duration of the corneal disease, treatment history, clinical appearance, and microbiology results. Veterinary Ophthalmology, v.17, p.6-13, 2013. Available from: <http:// onlinelibrary.wiley.com>. Accessed: Feb. 24, 2016. doi: 10.1111/ vop. 12103.

GOLEBIOWSKY, B. et al. Assessing the sensory function of the ocular surface: implications of use of a non-contact air aesthesiometer versus the Cochet Bonnet aesthesiometer. Experimental Eye Research, v.92, p.408-413, 2011. Avaliable from: <http://www.sciencedirect.com/science/ article/pii/S001448351100073X>. Accessed: Feb. 11, 2016. doi: 10.1016/j.exer.2011.02.016.

KAPS, S. et al. Corneal esthesiometry in the healthy horse. Veterinary Ophthalmology, v.6, p.151-155, 2003. Available from: $<$ https://www.ncbi.nlm.nih.gov/pubmed/12753618>. Accessed: Feb. 10, 2016. doi: 10.1046/j.1463-5224.2003.00283.x.

KOBASHIGAWA, K.K. et al. Ophthalmic parameters in adult Shih Tzu dogs. Ciência Rural, v.45, p.1280-1285, 2015. Avaliable from: <http://www.scielo.br/scielo.php?script=sci artte xt\&pid $=$ S0103-84782015000701280>. Accessed: Jan. 11, 2016. doi: 10.1590/0103-8478cr20141214.x.

LACERDA, R.P. et al. A comparative study of corneal sensitivity in birds of prey. Veterinary Ophthalmology, v.17, p.190-194, 2014. Avaliable from: <http://onlinelibrary.wiley.com/doi/10.1111/ vop.12068/>. Accessed: Jan. 14, 2016. doi: 10.1111/vop.12068.

LIMA, L. et al. The chinchilla eye: morphologic observations, echobiometric findings and reference values for selected ophthalmic diagnostic tests. Veterinary Ophthalmology, v.13, p.14-25, 2010. Avaliable from: <http://onlinelibrary.wiley.com/>. Accessed: Jan. 11, 2016. doi: 10.1111/j.1463-5224.2010.00785.x.

MILLODOT, M. A review of research on the sensitivity of the cornea. Ophthalmic and Physiological Optics, v.4, p.305318, 1984. Avaliable from: <http://onlinelibrary.wiley.com/ doi/10.1111/j.1475-1313.1984.tb00372.x/>. Accessed: Feb. 14, 2016. doi: 10.1111/j.1475-1313.1984.tb00372.x.

MONÇÃO-SILVA, R. et al. Ophthalmic diagnostic tests in parrots (Amazona amazonica) and (Amazona aestiva). Journal of Exotic Pet Medicine, v.25, p.186-193, 2016. Avaliable from: <www. exoticpetmedicine.com/article/S1557-5063(16)30056-8/pdf>. Accessed: Aug. 12, 2016. doi: 10.1053/j.jepm.2016.05.002.

MÜLLER, L. et al. Corneal nerves: structure, contents and function. Veterinary Ophthalmology, v.76, p.521-542, 2003. Available from: $<$ https://www.researchgate.net/publication/10803746>. Accessed: Dec. 20, 2015. doi: 10.1016/S0014-4835(03)00050-2.

MÜLLER, K. et al. Reference values for selected ophthalmic diagnostic tests and clinical characteristics of chinchilla eyes (Chinchilla lanigera). Veterinary Ophthalmology, v.13, p.2934, 2010. Avaliable from: <http://onlinelibrary.wiley.com/>. Accessed: Jan. 11, 2016. doi: 10.1111/j.1463-5224.2010.00801.x.

RANKIN, A.J. et al. Corneal sensitivity in healthy, immature, and adult alpacas. Veterinary Ophthalmology, v.15, p.31-35, 2012. Avaliable from: <http://onlinelibrary.wiley.com/doi/10.1 111/j.1463-5224.2011.00910.x>. Accessed: Jan. 13, 2016. doi: 10.1111/j.1463-5224.2010.00801.x.

WELIHOZKIY A. et al. Measurement of corneal sensitivity in 20 ophthalmologically normal alpacas. Veterinary Ophthalmology, v.14, p.333-336, 2011. Avaliable from: <http://onlinelibrary.wiley. com/doi/10.1111/j.1463-5224.2011.00895.x>. Accessed: Jan. 12, 2016. doi: 10.1111/j.1463-5224.2011.00895.x.

WIESER, B. et al. Correlation between corneal sensitivity and quantity of reflex tearing in cows, horses, goats, sheep, dogs, cats, rabbits, and guinea pigs. Veterinary Ophthalmology, v.16, p.251-262, 2013. Available from: $<$ http://onlinelibrary.wiley.com/ doi/10.1111/j.1463-5224.2012.01069.x/>. Accessed: Jan. 11, 2016. doi: 10.1111/j.1463-5224.2012.01069.x.

SOMMA, A.T. et al. The eye of the red-eared slider turtle: morphologic observations and reference values for selected ophthalmic diagnostic tests. Veterinary Ophthalmology, v.18, p.61-70, 2015. Available from: <http://onlinelibrary.wiley.com/ doi/10.1111/vop.12213/>. Accessed: Jan. 22, 2016. doi: 10.1111/ vop. 12213.

SADEK, M.H. et al. Factor analysis of body measurement in Arabian horses. Journal of Animal Breeding and Genetics, v.123, p.369-377, 2006. Available from: <http://onlinelibrary. wiley.com/doi/10.1111/j.1439-0388.2006.00618.x/>. Accessed: Feb. 10, 2016. doi: 10.1111/j.1439-0388.2006.00618.x. 